\title{
Resolution of Lipid Content from Algal Growth in Carbon Sequestration Studies
}

\author{
Indhumathi Ponnuswamy, Soundararajan Madhavan, Syed Shabudeen* \\ and Shoba U. S. \\ Department of Chemistry, Kumaraguru College of Technology, \\ Coimbatore-641049, Tamilnadu, India \\ cuteindhu@gmail.com,soundararajanbt@gmail.com,shabu_cbe@yahoo.com
}

\begin{abstract}
Green microalgae species was collected from Bhavani Lake of Erode in Erode District, Tamilnadu State, India. The Morphological studies were examined by utilizing Fourier Transform Infrared Spectroscopy, Microscope studies, Scanning Electron Microscopic studies and isolated and identified by PCR studies and by these studies that the collected specimen is to be Chlorella sp. In this study to check growth behavior and tolerance of fresh water green algae chlorella sp, under different $p H$,Temperature, different concentrations of sodium bicarbonate salt, carbon dioxide gas and under different levels of sodium chloride salt.. From the study it is clear that optimum levels of proper carbon source and salinity is very much essential for growing Chorella sp., as they influences its growth rate, biomass and lipid productivity. The experiment aims to analyze the biomass productivity and total lipid content of the microalgae strain under various growth conditions. All the cultures were grown for a period of 10 days. For the growth study reveals that, $p H$ range 4-7, Temperature 26-40, sodium bicarbonate salt concentrations 50-60 $\mathrm{mg} / \mathrm{l}$, sodium chloride concentration 0.02, maximum growth rate was observed, when CO2 gas was supplied at $40 \%$ concentration, maximum growth and maximum lipid yield of 15 in \%dry cell weight were recorded. A highest total lipid content of $20 \%$ was obtained.
\end{abstract}

Keywords: Algae, Carbon dioxide, salinity, lipid content

\section{Introduction}

Global warming induced by increasing concentrations of greenhouse gases in the atmosphere is a matter of great environmental concern. Carbon dioxide is the principal greenhouse gas. Atmospheric $\mathrm{CO}_{2}$ has increased from 280 to $368 \mathrm{ppm}$ in the last 200 years and is responsible for about 50\% enhancement in the greenhouse effect [10]. Annual anthropogenic emissions of $\mathrm{CO}_{2}$ are estimated to be $2 \times 10^{10}$ tons, primarily from combustion of fossil fuels in association with an increasing population and industrialization [3-5]. Recently, many attempts have been made to reduce atmospheric $\mathrm{CO}_{2}$. Physical and chemical treatments have been used to separate and recover $\mathrm{CO}_{2}$.

Utilization of $\mathrm{CO}_{2}$ by microalgae is among the most productive biological methods of treating industrial waste emissions, and the yield of biomass per acre is three to fivefold greater than from typical crops [7 and 14]. Direct use of flue gas reduces the cost of

${ }^{*}$ Corresponding Author 
pretreatment, but the high concentration of $\mathrm{CO}_{2}$ and the presence of SOx and NOx inhibit the growth of cyanobacteria and microalgae [12].

Algae are a large and diverse group of simple aquatic organisms ranging from unicellular to multi cellular forms, they mainly grow based on the photosynthesis mechanism, just like the plants, they capture the light energy to fuel the manufacture of sugars. They are simple creatures living in the marine and fresh water biological systems [8]. Many aquatic creatures such as fish and shrimp take the algae as their main food.

Algae play an important role in the global ecosystem. With the arising of global warming and GHG emission issue, algae are also studied to capture the carbon dioxide [1\&2]. The potential ability of microalgae is positive, through the related theoretic calculations, the result is that per kilogram microalgae could capture nearly $1.83 \mathrm{~kg} \mathrm{CO} 2$ [7].

The microalgae have much higher growth rate than the most land-based plant due their higher photosynthesis efficiency. Algae have much shorter growth cycle, the weight double time is about three to five days and some species can have two harvest seasons in one day. The algae yield weight per year is nearly several times or even hundred times of food crop yield.

The goal of this study is to isolate microalgae in Coimbatore which can tolerate high $\mathrm{CO}_{2}$ concentrations and high temperatures in order to sequestrate carbon dioxide and discover the optimal conditions for biomass production.

\section{Materials and Methods}

\subsection{Sources of Algae Sample}

Microalgae were isolated from several samples taken from rivers, lakes, ponds, of Erode and Coimbatore, KCT Hostel waste water was used as culture media for algae growth.

They were explored in terms of growth study in air, different $\mathrm{pH}$, different concentration of sodium bicarbonate salt $\left(\mathrm{NaHCO}_{3}\right)$, different concentration of carbon dioxide gas, different concentrations of Sodium chloride salt, Further, from the experimental finding it is observed that the strain can efficiently utilize $\mathrm{CO}_{2}$ gas and bicarbonate, as carbon source, but $\mathrm{CO}_{2}$ gas has a poor dissolving capacity and most of it tend to lost in the air so it is convenient to use bicarbonate form instead of $\mathrm{CO}_{2}$ gas, as microalgae cells have the machinery to convert bicarbonate salt into $\mathrm{CO}_{2}$ with the help of the enzyme carbonic anhydrase so that there is efficient fixation of $\mathrm{CO} 2$ occurs with the help of another enzyme rubisco (ribulose 1,5 bis phosphate).

The $\mathrm{pH}$ of the cultures was elevated 2 to 10 . Culture flasks each having different concentration of bicarbonate salts, gaseous $\mathrm{CO} 2$ and sodium chloride salts were prepared separately for each of the experiment. For bicarbonate growth study of the aforementioned strain, $\mathrm{NaHCO}_{3}$ salt in the concentration ranges of 20,40, 60, 80 and $100 \mathrm{mg} / \mathrm{L}$ $(1 \mathrm{mg} / \mathrm{L}=1 \mathrm{ppm})$ were freshly weighed and added to each of the flasks. For salinity tolerance $\mathrm{NaCl}$ salt in different concentrations $0.02,0.04,0.06,0.08 \& 0.10$ Molar were added.

Gaseous CO2 is supplied to cultures in the concentrations of $10 \%, 20 \%, 30 \%, 40 \%, 50 \%$. Then $\mathrm{CO} 2$ gas is supplied till the $\mathrm{pH}$ falls high to low, so that mentioned amount of $\mathrm{CO} 2$ concentration can be reached. Because of poor solubility of $\mathrm{CO} 2$ gas, there is periodical (every after $6 \mathrm{hrs}$ ) addition of $\mathrm{CO} 2$ gas by checking and maintaining the $\mathrm{pH}$ of the cultures. A constant supply of carbon dioxide gas at $120 \mathrm{ml} / \mathrm{min}$ was maintained by using a digital gas flow meter (Digital Gas Flow Meter, Model: DFM-01 / 02 / 03). Biomass increase per day (mg/L/day), cell no increase per day and Optical Densities were taken daily for growth characteristics of the strain. The strain was checked for 9 days of growth period in varying amount of carbon dioxide gas. 


\subsection{Analytical Method}

Light microscopic cell count by was performed using optical microscope (Ample). Optical densities of microalgae cultures were measured at a regular interval of time (24Hrs) by checking absorbance at 680nm with the help of spectrophotometer (Thermo Evolution-201) in three replicates and average value was recorded. The spectrophotometer was blanked every time with each medium respectively. At the end of the experiment all the culture flasks were centrifuged \& filtered and dry weights of pellets were measured (80.C for $3 \mathrm{hrs}$ ) to study the increase in biomass, cell count and lipid content and further studies.

\section{Result and Discussion}

\subsection{Effect of carbon dioxide emission}

India is famous for the largest population, now India is entering a brand new era with the rapid economic development. Unfortunately, the main energy source of India is still coal, oil, natural gas such fossil fuels. Besides, a tremendously large scale of infrastructure construction is under going, the manufacturing industry is booming, more and more vehicles are showing on the road, the people's living standard and welfare is promoting as the same. The country is consuming more and more fossil energy. However, as a result, the carbon dioxide emission amount is rocketing with the increasing energy demand. Due to these reasons, the increasing carbon dioxide emission in India is shown Figure 1.

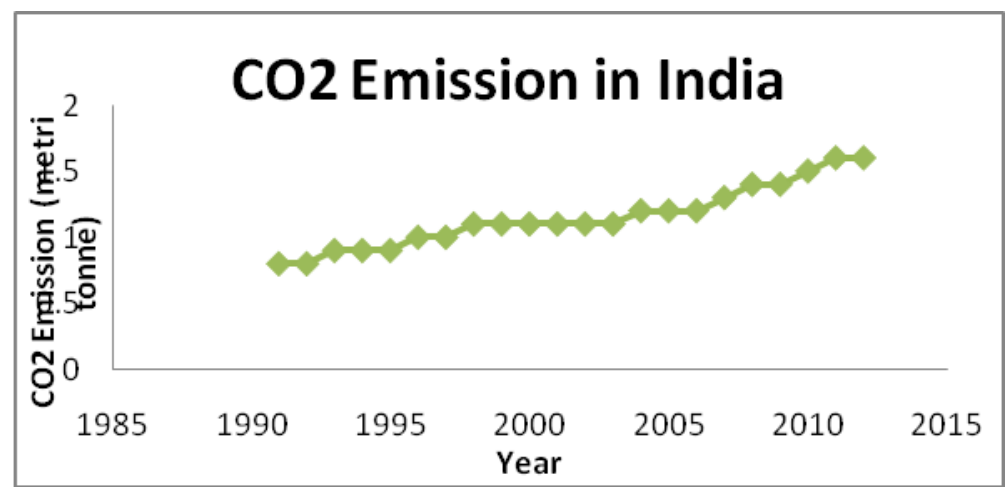

Figure 1. Carbon Dioxide Emmision in India

India needs to take actions to reduce the carbon dioxide emission, as one important role in the world's sustainable development, India must takes relative international responsibility, and the Chinese government has promised that the carbon dioxide emission per capita must be reduced by $50 \%-60 \%$ in 2020 compared with 2005 . It is a big challenge for India.

Table 1. The Rank of Carbon Dioxide Emission in the World [CARMA, 2011]

\begin{tabular}{|l|l|l|l|}
\hline Nation & Area & TONS CO $_{2}$ & RANK \\
\hline China & Asia & 3120000000 & 1 \\
\hline Us & North America & 2820000000 & 2 \\
\hline India & Asia & 638000000 & 3 \\
\hline Russia & Europe & 478000000 & 4 \\
\hline
\end{tabular}




\begin{tabular}{|l|l|l|l|}
\hline Germany & Europe & 429000000 & 5 \\
\hline \multicolumn{2}{|c|}{ Structure of Energy Consumption in India } \\
\hline \multirow{5}{*}{} & Industry & $41 \%$ & \\
& Transport & $18 \%$ & \\
& Residential & $14 \%$ & \\
& Commercial & $2 \%$ & \\
& Other energy & $8 \%$ & \\
& uses & $9 \%$ & \\
& Non-energy uses & & \\
& Agriculture & 8 & \\
\hline
\end{tabular}

\subsection{Identification of Isolated Microalgae}

Some morphological and chemical characteristics of this isolates, unicellular green micro with a diameter of 3-6 $\mu \mathrm{m}$. Each cell had one cup-shaped chloroplast with a distinctive pyrenoid, Figure 2.

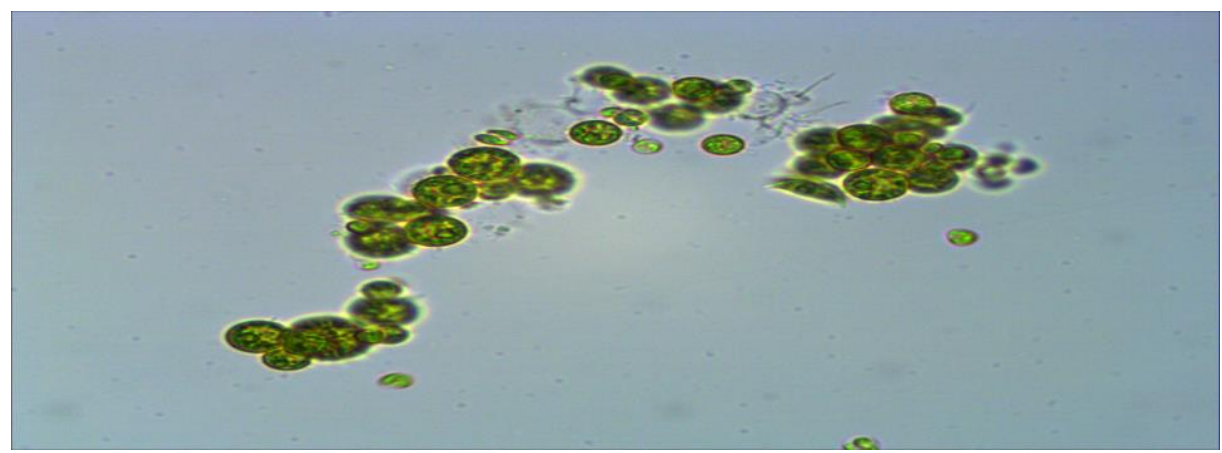

Figure 2. light microscopic image of chlorella sp

\subsection{Effect of $P h$}

The linear growth rate of Chlorella $\mathrm{sp}$. was $10 \mathrm{~g} / \mathrm{l}$ at an initial $\mathrm{pH}$ of 2 to10, increased gradually to $24 \mathrm{mg} / \mathrm{L}$ at a $\mathrm{pH}$ of 6.0 , and remained constant at a $\mathrm{pH}$ of 7.0. The cell growth of Chlorella sp. was inhibited at an initial pH below 3.0. [11-12] also reported that the growth of Chlorella was not affected by culture $\mathrm{pH}$ when the value was higher than $\mathrm{pH} 4.0$, and the growth rate was inhibited drastically at $\mathrm{pH}$ 3.0. The culture was color changed. In this study, Chlorella sp. was able to grow at $\mathrm{pH} 4.0$ to 7.0 shown in Figure 3. This characteristic is very important and suitable for stack gases using the cultivation of Chlorella for biomass production. 


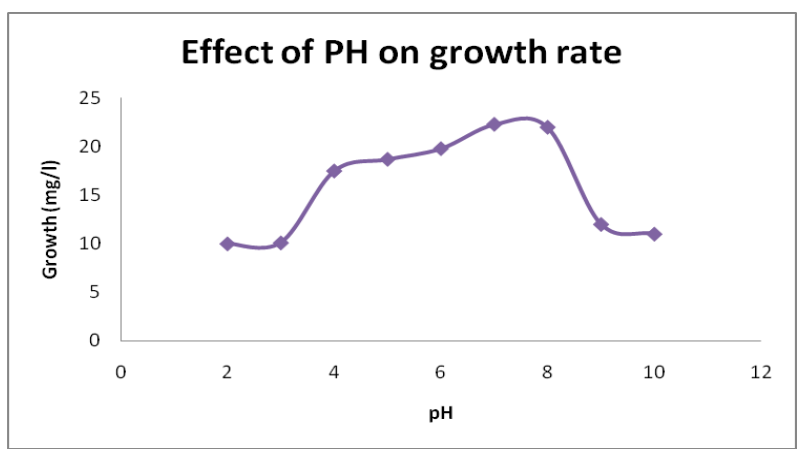

Figure 3. Effect of $\mathrm{p} \mathrm{H}$ on growth rate

\subsection{Effect of Cultivation Temperature}

The growth rates of the Chlorella isolates showed in Figure 4 significant inhibition at incubation temperatures $25^{\circ} \mathrm{C}$ to $40^{\circ} \mathrm{C}$. Chlorella sp. had a high growth rate at 35 and $40^{\circ} \mathrm{C}$ while Chlorella sp. had a high value at $30^{\circ} \mathrm{C}\left(\mathrm{A}_{680 \mathrm{~nm}}=1.51\right)$. The optical density was only 0.05 to 0.20 when they were cultivated at $25,30,35$ and $40^{\circ} \mathrm{C}$.

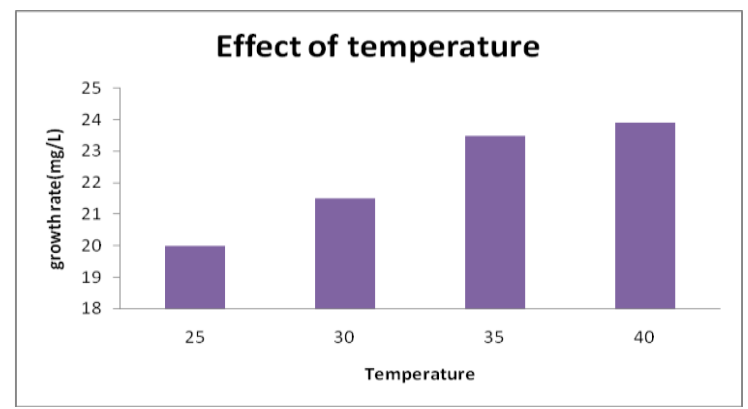

Figure 4. Effect of Temperature on Growth Rate

\subsection{Effect of Light Intensity}

Light condition, especially light intensity, is an important factor because the light energy drives Photosynthesis. Typical light intensity requirements of microalgae are relatively low in comparison to higher plants. For example, saturating light intensity of Chlorella sp. Is approximately $200 \mathrm{~mol} / \mathrm{sec} / \mathrm{m} 2$ [9]. Microalgae often exhibit photo inhibition under excess light conditions. Photo inhibition is often suspected as the major cause of reducing algal productivity. The use of a photo bioreactor with a solar collector device for the $\mathrm{CO} 2$ mitigation has been explored. Maximum light intensity of $15.7 \mathrm{Wm}-2$ could be attained using the system, and the culture of Chlorella sp. could be maintained. The efficiency of light collection and transmission to the algal cells was $8-10 \%$ (. Recently, improvements are being made to the solar collecting devices.

The system can utilize infrared heat as well as visible light. In addition, artificial lighting is combined so that lighting is possible when there is no natural sunlight. The use of such novel solar collecting and distributing devices would improve CO2 sequestration efficiency. Low light intensity reduced the growth rate and biomass production. Culture not grown on dark cycle.

The effect of light intensity on the photosynthetic oxygen evolution of Chlorella sp. increased with the increasing of light intensity. Therefore, the growth rate of Chlorella sp. 
might be improved if the cultures were grown under high light intensity and a sufficient nutrient supply.

\subsection{Effect of $\mathrm{CO}_{2}$ Concentration on Cell Growth}

To investigate the effect of $\mathrm{CO}_{2}$ concentration on the growth of the isolated microalgae, were incubated at $30^{\circ} \mathrm{C}$ under aeration with different concentrations of $\mathrm{CO}_{2}$ at $0.15 \mathrm{vvm}$ for 6 to 10 days. It was shown that microalgae grew slowly in air aeration condition. When these isolates were incubated under aeration with $10 \%-40 \% \mathrm{CO}_{2}$, isolates had an optical density at $680 \mathrm{~nm}$ higher than 2.0, tested isolates over 10 day's cultivation.

Flue gas contains 13 to $15 \% \mathrm{CO}_{2}$, meaning these isolated microalgae were incubated at $30^{\circ} \mathrm{C}$ and $589 \mu \mathrm{mol} \mathrm{m} \mathrm{m}^{-2} \mathrm{~s}^{-1}$ under aeration with $10 \% \mathrm{CO}_{2}$. Cell dry weight increased on incubation. Isolate had a cell dry weight higher than $1.6 \mathrm{~g} \mathrm{l}^{-1}$, and the maximal growth rate was more than $0.18 \mathrm{~g} \mathrm{l}^{-1} \mathrm{~d}^{-1}$.

The specific growth rate of this isolate was between 0.177 and $0.271 \mathrm{~d}^{-1}$ during 2 to 8 days incubation. Isolates had high cell biomass and appropriate specific growth rate during 2 to 5 days cultivation.

The effect of $\mathrm{CO}_{2}$ concentration on the cell growth of Chlorella sp. is shown in Figure 1. Aeration with addition of $\mathrm{CO}_{2}$ stimulated cell growth, and strain had a maximal growth at $10 \% \mathrm{CO}_{2}$, which decreased gradually with increasing $\mathrm{CO}_{2}$ concentration. A long lag period was observed under aeration with $40 \% \mathrm{CO}_{2}$, and the cell growth decreased significantly. Strain had a maximal linear growth rate under aeration with $40 \% \mathrm{CO}_{2}$ (between 0.28 and $0.31 \mathrm{~g} \mathrm{l}^{-1} \mathrm{~d}^{-1}$ ). This rate decreased slightly under aeration with 20 to $30 \% \mathrm{CO}_{2}$ (from 0.21 to $0.27 \mathrm{~g} \mathrm{l}^{-1} \mathrm{~d}^{-1}$ ), fell moderately under aeration with $10 \% \mathrm{CO}_{2}$ (between 0.15 and $0.18 \mathrm{~g} \mathrm{l}^{-1} \mathrm{~d}^{-1}$ ), and plunged under aeration with $60 \% \mathrm{CO}_{2}$ (between 0.06 and $0.07 \mathrm{~g} \mathrm{l}^{-1} \mathrm{~d}^{-1}$ [9] indicated that $\mathrm{CO}_{2}$-tolerant microalgae, Chlorella sp., had growth rates between 0.15 and $0.18 \mathrm{~g} \mathrm{l}^{-1} \mathrm{~d}^{-1}$ at 10 to $40 \% \mathrm{CO}_{2}$, and they could not grow at $60 \% \mathrm{CO}_{2}$. The growth rate of isolates of Chlorella sp. might be improved by the adaptation of carbon dioxide enrichment and by the adjustment of culture conditions.

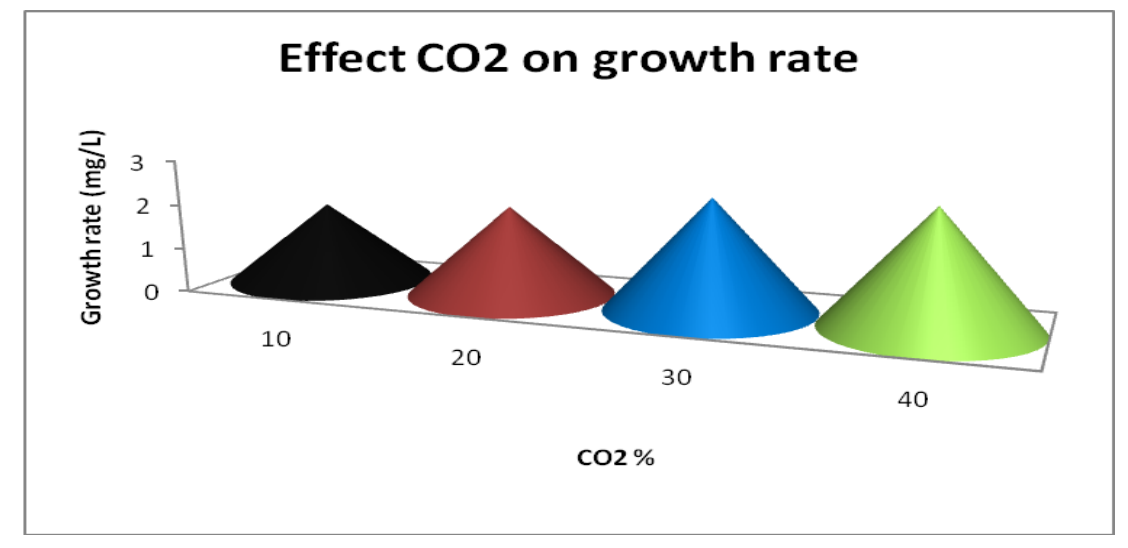

Figure 5. Effect of $\mathrm{CO} 2$ on Growth Rate

\subsection{Effect of Salt Concentration Growth Rate and Lipid Production}

The aforementioned algae strain showed a good growth under different nutrition environments such as variable concentrations of bicarbonate, carbon dioxide gas and salinity. The growth behavior of the strains under different bicarbonate levels are shown in Figure 6, 
the bicarbonate concentration at which maximum growth rate was obtained was at $60 \mathrm{mg} / \mathrm{L}$ (ppm). Jeong found that $15.3 \mathrm{mg} / \mathrm{L}$ bicarbonate salt is equivalent to $243 \mathrm{mg} / \mathrm{L} \mathrm{CO} 2$ gas in our strain showed its best growth at $952.9 \mathrm{mg} / \mathrm{L} \mathrm{CO} 2$ gas which is equivalent to $60 \mathrm{mg} / \mathrm{L}$ bicarbonate. The total lipid content in terms of \% dry cell weight was $18.2 \%$.

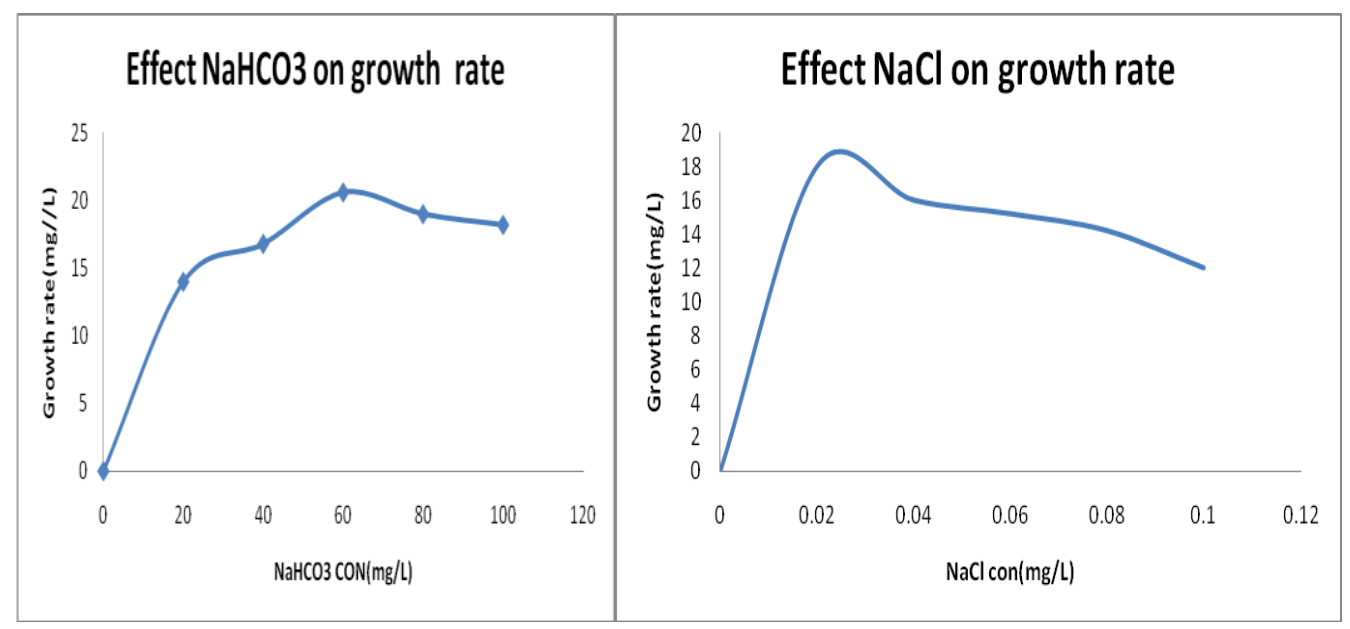

Figure 6. Effect of Salt Concentration on Growth Rate

The maximum total lipid was found to be $15 \%$ in terms of dry cell weight (Figure 6). It was noticed that a higher flow rate inhibited algal growth. Also a higher concentration of $\mathrm{CO} 2$ in the media is lethal to algae strains because it results in decreasing $\mathrm{pH}$ as it leads to carbonic acid production. The alga can optimally grow in the $\mathrm{pH}$ range of 4-7. Highest lipid content was found in case of $0.02 \mathrm{M}$ salinity, $60 \mathrm{mg} / \mathrm{L}$ of bicarbonate salt concentration and $40 \%$ of $\mathrm{CO}_{2}$.

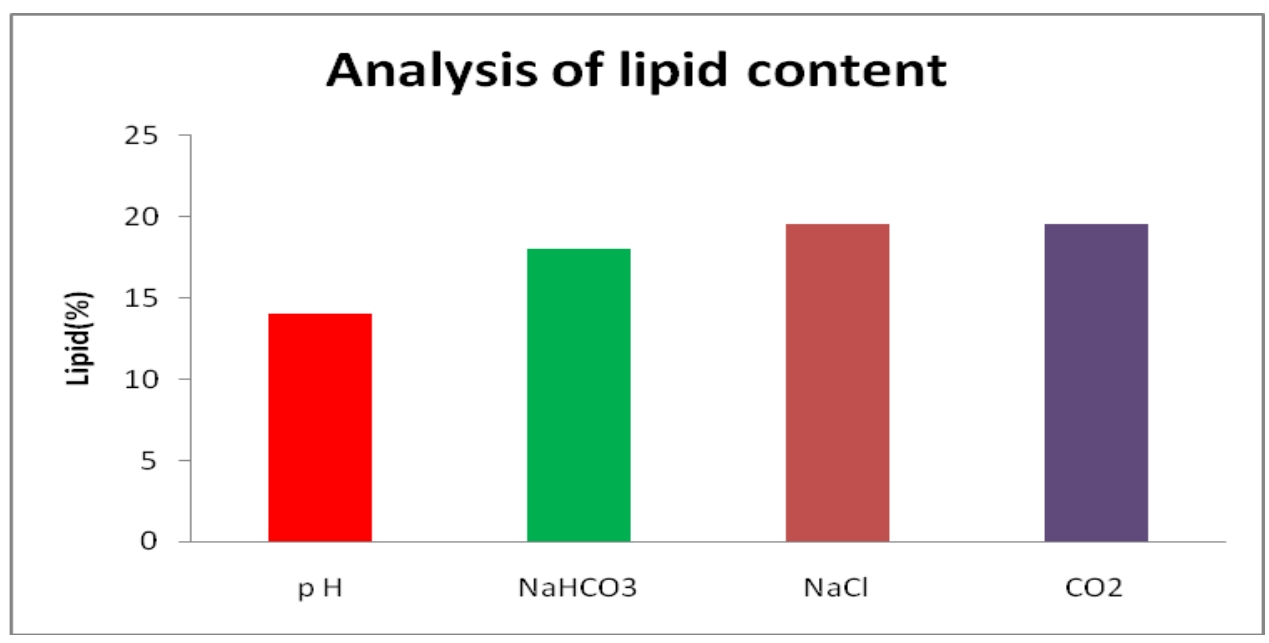

Figure 7. Total Lipid Production in Different Condition

\section{Conclusion}

In conclusion, the local isolates Chlorella sp. grew well at high temperature, high cell density, high $\mathrm{CO}_{2}$ concentration, and over a broad-range of $\mathrm{pH}$ values. They are suitable 
strains for large-scale, dense cultivation with industrial discharge gases to fix $\mathrm{CO}_{2}$ directly to reduce global warming and create a cell biomass for producing industrially valuable compounds.

The cultivation system for

- high photo efficiency,

- less space,

- cheap cost,

- high productivity,

- easy management,

- high reliability,

- The cultivation system needs to be improved to be climate independence.

- Harvesting methods should be improved to consume less energy and higher efficiency.

\section{Acknowledgements}

The authors wish to express the gratitude for the support and financial help given by Department of Science and Technology, New Delhi for their support under Net Work Programme of Bio-Algae Carbon Sequestration research under the title "Carbon Sequestration and cultivating algae for green bio-fuel Production".

\section{References}

[1] Arizona Department of Environmental Quality, Arizona guidance manual for constructed wetlands for water quality improvement, Arizona Department of Environmental Quality, Arizona, (1995).

[2] D. J. Bayless, G. G. Kremer, M. E. Prudich, B. J. Stuart, M. L. Vis-Chiasson, K. Cooksey and Muhs, "Enhanced practical photosynthetic CO2 mitigation", Proceedings of the first national conference on carbon sequestration, vo. 54A, (2001), pp. 1-14.

[3] E. W. Becker, "Microalgae: Biotechnology and microbiology", Cambridge University press, Cambridge, Great Britain, (1994), pp. 293.

[4] J. R. Benemann, "Utilization of carbon dioxide from fossil fuel - burning power plants with biological system", Energy conversion and management, vol. 34, no. 9/11, (1993), pp. 999-1004.

[5] J. R. Benemann, "CO2 mitigation with microalgae systems", Energy conversion and management (Suppl), vol. 38, (1997), pp. S475-S479.

[6] P. Bennett, “Ashfield's alternative”, Landscape Architecture, vol. 88, no. 1, (1998), pp. 44-49.

[7] L. Brennan and P. Owende, "Biofuels from microalgae- A review of technologies for production, processing, and extractions of biofuels and co-products", Renewable and Sustainable Energy Reviews, vol. 14, (2010), pp. 557-577.

[8] L. E. Graham, L. W. Wilcox, Algae, Prentice-Hall, Inc., Upper Saddle River, NJ, (2000), pp. 640.

[9] N. Hanagata, T. Takeuchi, Y. Fukuju, D. J. Barnes and I. Karube, "Tolerance of microalgae to high CO2 and high temperature", Phytochemistry, vol. 31, no. 10, (1992), pp. 3345-3348.

[10] I. Karube, T. Takeuchi and D. J. Barnes, "Biotechnological reduction of $\mathrm{CO}_{2}$ emissions", Adv. Biochem. Eng./Biotech, vol. 46, (1992), pp. 63-79.

[11] M. Kodama, H. Ikemoto and S. Miyachi, "A new species of highly CO2-tolreant fast-growing marine microalga suitable for high-density culture", Journal of marine biotechnology, vol. 1, (1993), pp. 21-25.

[12] N. H. Kurano, H. Ikemoto, T. Miyashita, Hasegawa and S. Miyachi, "Carbon dioxide uptake rate of Chlorococcum littorale", Mar. Biotech, vol. 3, (1995), pp. 108-110.

[13] K. Maeda, M. Owada, N. Kimura, K. Omata and I. Karube, "CO2 fixation from the flue gas on coalfired thermal power plant by microalgae", Energy convers. Mgmt., vol. 36, (1995), pp. 717-720. 
[14] E. A. Laws and J. L. Berning, "A study of the energetics and economics of microalgal mass culture with the marine chlorophyte Tetraselmis suecica: implications for use of power plant stack gases", Biotechnology and bioengineering, vol. 37, (1991), pp. 936-947.

\section{Author}

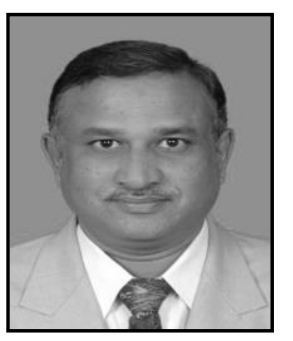

\section{Syed Shabudeen}

He received his B. Sc., M. Sc (Chemistry) from Madars University, and $\mathrm{Ph}$. D(Environmental Chemistry) from Bharatiar University, Coimbatore. Worked as Professor to the Department of Chemistry, Kumaraguru College of Technology, Coimbatore. He has 30 years of experience in Teaching. His major research interest is Environmental Chemistry and Environmental Bio-Technology. He has published 37 Research Papers in International Journals and Conferences and 2 Text Books for chemistry. Govt. of India DST (Department of Science and Technology) New Delhi sanctioned Rs 54, 90,420 for carrying out the carbon sequestration research "Carbon Sequestration and Cultivation of Green Algae for Bio-fuel Production". 7 no.s of candidates pursuing Doctoral Degree in Chemistry and Environmental Science. 
International Journal of Advanced Science and Technology Vol.67 (2014) 